\title{
Efektivitas Layanan Penguasaan Konten Melalui Bimbingan Kelompok Belajar dalam Mengurangi Perilaku Menyontek Siswa saat Ujian
}

\author{
Endang Ningsih 1, Firman 2, Erlamsyah 3 \\ ${ }^{123}$ Universitas Negeri Padang \\ *Corresponding author, e-mail: endangnigsih373@gmail.com
}

\begin{abstract}
Abstrak
Penelitian ini dilatarbelakangi banyaknya isu siswa yang menyontek disaat ujian karena tidak menguasi materi ujian atau tidak memahami makna ujian yang sebenarnya. Penelitian ini bertujuan untuk melihat efektivitas layanan penguasaan konten menggunakan bimbingan kelompok belajar dalam mengurangi perilaku menyontek siswa saat ujian. Penelitian ini menggunakan pendekatan kuantitatif. Penelitian ini menggunakan rancangan Quasy-Experiment jenis The Non Equivalent Control Group. Subjek penelitian adalah siswa kelas VIII 1 dan VIII 2 SMPN 6 X Koto Singkarak. Teknik pengumpulan data menggunakan kuisioner yang dianalisis dengan teknik uji beda (t-test). Hasil penelitian menunjukan layanan penguasaan konten menggunakan bimbingan kelompok belajar dapat mengurangi perilaku menyontek siswa saat ujian dan lebih efektif digunakan dibandingkan dengan layanan penguasaan konten tanpa bimbingan kelompok belajar. Guru BK diharapkan dapat mengurangi perilaku menyontek siswa saat ujian menggunakan layanan penguasaan konten melalui bimbingan kelompok belajar.
\end{abstract}

Kata kunci : Layanan Penguasaan Konten, Bimbingan Kelompok Belajar, Perilaku Menyontek Siswa

How to Cite: Endang Ningsih 1, Firman 2, Erlamsyah 3. 2018. Efektivitas Layanan Penguasaan Konten Melalui Bimbingan Kelompok Belajar dalam Mengurangi Perilaku Menyontek Siswa saat Ujian, VV (N): pp. XX-XX, DOI:10.24036/XXXXXXXXXX-X-XX

This is an open access article distributed under the Creative Commons 4.0 Attribution License, which permits unrestricted use, distribution, and reproduction in any medium, provided the original work is properly cited. C2017 by author and Universitas Negeri Padang.

\section{Pendahuluan}

Pendidikan salah satu usaha untuk mencapai perkembangan yang optimal bagi peserta didik. Undangundang No. 20 Tahun 2003 tentang Sistem Pendidikan Nasional, Pasal 1 ayat 1 menjelaskan: Pendidikan adalah usaha sadar dan terencana untuk mewujudkan suasana belajar dan proses pembelajaran agar peserta didik secara aktif mengembangkan potensi diri, yang memiliki kekuatan spiritual keagamaan, pengendalian diri, kepribadian, kecerdasan, akhlak mulia, serta keterampilan.

Menurut Muhimbbin Syah (2008:154) untuk mengetahui apakah tujuan pendidikan tersebut sudah dicapai atau belum, maka perlu dilakukan evaluasi. Dalam dunai pendidikan, kata evaluasi lebih dikenal dengan kata tes, ujian, dan ulangan, dimana evaluasi merupakan penilaian terhadap tingkat keberhasilan siswa mencapai tujuan yang telah ditetapkan dalam sebuah program. Selanjutnya, menurut A. Muri Yusuf (2005:56) dillihat dari sisi kegiatan belajar-mengajar atau kegiatan pembelajaran, evaluasi merupakan pemberian pertimbangan, nilai dan arti terhadap data atau informasi yang dikumpulkan melalui pengukuran assesmen dengan standar sehingga melahirkan keputusan.

Salah satu cara pengembangan individu secara optimal dilakukan melalui proses belajar dan pembelajaran. Nana Sudjana (2004:15) "Belajar merupakan proses ditandai dengan adanya perubahan pada diri seseorang. Perubahan sebagai hasil proses belajar ditunjukkan dalam berbagai bentuk, seperti : perubahan pengetahuan, perubahan sikap, tingkah laku, keterampilan, kecakapan, dan kemampuan".

Dalam usaha untuk meraih keberhasilan mendapatkan nilai yang baik dalam ujian, ada siswa yang belajar dengan tekun dan ada pula siswa yang tidak belajar, akan tetapi mengandalkan teman atau berbuat curang, misalnya menyontek saat mengikuti ujian. Hal ini terjadi karena hasil ujian dan ulangan itu 
merupakan salah satu kriteria yang dipakai pendidikan atau pengajar dalam menentukan keberhasilan proses belajar-mengajar yang dilakukan. Menurut Rahmawati, dkk (2015 apabila dalam proses evaluasi hasil belajar (tes atau ujian) peserta didik melakukan kecurangan akademik atau menyontek, maka hasil tes tersebut bisa dikatakan bias. Tak dipungkuri lagi, dalam pelajaran ujian dan ulangan itu sebagian peserta didik mencontek (Silvano, dkk, 2008).

Menurut Prayitno \& Erman Amti (2004:280) " Tes hasil belajar adalah suatu alat yang disusun untuk mengungkapkan sejauh mana siswa telah mencapai tujuan-tujuan pengajaran yang ditetapkan sebelumnya". Tekanan yang dirasakan akan membuat siswa lebih berorientasi pada nilai, bukan pada ilmu. Siswa dapat mempersepsi ujian sebagai alat untuk menyusun peringkat dan dapat menyebabkan dirinya mengalami kegagalan, bukan sebagai instrument yang dapat menunjukkan kemajuan proses dalam proses belajar ( Sujana dan Wulan, 1994:2-3).

Menurut Rusydan (2014:2) menyontek adalah melakukan kegiatan yang bertujuan untuk mencari jawaban atas soal-soal ujian yang dilakukan dengan cara-cara tertentu sehingga tidak diketahui oleh orang lain. Sejalan dengan itu, menurut Kiki dan Hadjam (2015:12) perilaku menyontek adalah kegiatan, tindakan atau perbuatan curang dan tidak jujur yang menggunakan cara-cara yang tidak sah untuk memalsukan hasil belajar dengan menggunakan pendampingan atau memanfaatkan informasi dari luar secara tidak sah pada saat dilaksanakan tes atau evaluasi akademik. Dampak yang akan terjadi dari perilaku menyontek yang dilakukan oleh peserta didik secara terus menerus adalah peserta didik menjadi tidak memperdulikan proses belajar mengajar (Erlina Wilda (2013).

Penelitian yang dilakukan oleh Maysari (2015) hasil penelitiannya menyatakan bahwa perilaku menyontek siswa berada pada kategori tinggi. Sejalan dengan itu, menurut hasil penelitian dari Virza Agustin (2013) hasil penelitiannya menunjukkah bahwa perilaku menyontek siswa berada pada kategori tinggi.Hasil penelitian yang dilakukan oleh Dody Hartanto (2012:21) pada tahun 2010 perilaku yang paling sering dijumpai dalam menyontek adalah meminta informasi atau jawaban dari orang atau teman lain (paling dominan), memberikan izin kepada orang untuk menyalin pekerjaannya, dan/atau menyalin tugas orang lain. Berdasarkan hasil penelitian dari Tsany Lutfiyanti dan Mochamad Nursalim (2013:346) bahwa adanya perubahan skor dari 7 siswa setelah diberikan perlakuan bimbingan kelompok belajar.

Berdasarkan hasil wawancara dengan salah seorang guru di SMP Negeri 6 X Koto Singkarak pada tanggal 22 Agustus 2016 dapat diperoleh informasi bahwa masih banyak siswa yang melakukan perilaku menyontek di sekolah, baik dalam mengerjakan latihan, ulangan maupun dalam ujian. Siswa yang menyontek terkadang takut jika tidak memberikan contekan kepada teman yang bertanya, selain itu siswa menyontek karena kurang memahami makna ujian yang sebenarnya dan tidak tau cara tepat dalam menjawab ujian sehingga tidak kehabisan waktu untuk mencari jawaban ujian. Hal inilah yang terkadang mendorong siswa untuk mau dan terbiasa menyontek.

Berdasarkan hasil wawancara dengan 5 orang siswa di SMP Negeri 6 X Koto Singkarak pada tanggal 22 Agustus 2016 diperoleh informasi bahwa siswa tersebut masih melakukan perilaku menyontek dikarenakan mereka takut dikucilkan dan tidak disukai oleh teman sekelas mereka apabila mereka tidak mau memberikan contekan.

Hurlock (1980:209-210) mengemukakan bahwa sekolah dan pendidikan tinggi menekankan perkembangan keterampilan intelektual dan konsep yang penting bagi kecakapan sosial. Namun, hanya sedikit remaja yang mampu menggunakan keterampilan dan konsep ini dalam situasi praktis. Mereka yang aktif dalam berbagai aktivitas ekstrakurikuler menguasai praktek demikian namun mereka yang tidak aktif karena harus bekerja setelah sekolah atau karena tidak diterima oleh teman-teman tidak memperoleh kesempatan ini.

Sekolah dan pendidikan tinggi juga mencoba untuk membentuk nilai-nilai yang sesuai dengan nilainilai dewasa, orang tua berperan banyak dalam perkembangan ini. Namun bila nilai-nilai dengan dewasa bertentangan dengan nilai-nilai teman sebaya, maka remaja harus memilih yang terakhir bila mengharapkan dukungan teman-teman yang menentukan sosial mereka.

Perilaku menyontek yang dilakukan oleh remaja menandakan bahwa ketidakberhasilan remaja dalam mencapai tugas-tugas perkembangan yaitu dalam hal perilaku moral, dimana hal ini diperkuat oleh pendapat Hurlock (1980:238) penyesuaian sosial remaja dapat dirusak oleh pelanggaran peraturan dan hukum. Beberapa remaja mengabaikan peraturan dan hukum-hukum yang diharapkan untuk dipatuhi, dan beberapa lainnya tidak mampu mempelajari apa yang benar dan apa yang salah. Sejalan dengan itu, menurut Intan Sari,dkk (2013) keterkaitan pada kelompok pada periode remaja dapat diamati pada siswa yang iktu-ikutan teman dalam memilih bimbingan belajar sebagai persiapan UN. Sejalan dengan itu, menurut Rohana (2015:653) melihat teman saling menyontek membuat siswa untuk belajar meniru perilaku tersebut.

Menurut Ormrod (2009:112) sebagai guru, kita harus senantiasa ingat bahwa sebagian besar siswa berupaya sungguh-sungguh untuk tampil baik dihadapan teman-temannya. Kita dapat membantu mereka

Efektivitas Layanan Penguasaan Konten Melalui Bimbingan Kelompok Belajar dalam Mengurangi Perilaku Menyontek Siswa saat Ujian 
mempertahankan citra publik yang baik melalui beragam cara. Sebagai contoh, kita dapat membantu mereka menguasai keterampilan-keterampilan yang mereka perlukan seperti teknik berbicara di depan publik, kebersihan pribadi, dan sebagainya, sehingga mereka dapat menampilkan diri sebaik mungkin.

Dalam bimbingan dan konseling ada salah satu jenis layanan yang bisa meningkatkan keterampilan belajar siswa sehingga siswa bisa mengurangi kebiasaan menyontek dalam belajar yaitu layanan penguasaan konten. Menurut Prayitno (dalam Tohirin, 2009:158) layanan penguasaan konten merupakan suatu layanan bantuan kepada individu (siswa) baik sendiri maupun dalam kelompok untuk menguasai kemampuan atau kompetensi tertentu melalui kegiatan belajar. Dengan penguasaan konten, individu (siswa) diharapkan mampu memenuhi kebutuhannya serta mengatasi masalah-masalah yang dialaminya. Layanan penguasaan konten a) melalui bimbingan kelompok belajar memiliki tujuan yaitu membiasakan anak bergaul dengan teman-temannya, bagaimana mengemukakan pendapat dan menerima pendapat dari teman lain. b) belajar secara kelompok turut pula merealisasikan tujuan pendidikan dan pengajaran, c) untuk belajar mengatasi kesullitan secara bersama-sama, terutama dalam hal pelajaran, d) belajar hidup bersama agar nantinya tidak canggung di dalam masyarakat yang lebih luas dan e) memupuk rasa kegotong-royongan yang merupakan sifat dari bangsa Indonesia (Menurut Bimo Walgito,2010:124-125).

Berdasarkan uraian tersebut, peneliti tertarik untuk meneliti "Efektifitas Layanan Penguasaan Konten Melalui Bimbingan Kelompok Belajar dalam Mengurangi Perilaku Menyontek Siswa Saat Ujian".

\section{Metode}

Jenis penelitian ini merupakan penelitian Quasi Eksperiment.Subjek penelitian meliputi kelas VIII 1 sebagai kelas kontrol dan kelas VIII 2 SMPN 6 X Koto Singkarak sebagai kelompok eksperimen. Untuk mengumpulkan data, digunakan instrumen penelitian berupa angket skala model Likert untuk pretest dan untuk posttest. Untuk menganalisis hasil penelitian, peneliti menggunakan teknik uji beda ( $t$-test) dengan bantuan program SPSS versi 20.00 dan Microsoft Excell 2007. Menurut Trianto (2011:203) penelitian eksperimen dapat didefinisikan sebagai metode sistematis guna membangun hubung an yang mengandung fenomena sebab akibat. Menurut Punaji Setyosari (2013:183) rancangan penelitian eksperimen kuasi dalam kaitannya dengan pemilihan subjek penelitian, peneliti tidak selalu dapat melakukan pemilihan subjek secara random. Sejalan dengan itu menurut Sumadi Suryabrata (2012:92) tujuan Quasi Experiment atau eksperimen semu adalah untuk memperoleh informasi yang merupakan perkiraan bagi informasi yang dapat diperoleh dengan eksperimen yang sebenarnya dalam keadaan yang tidak memungkinkan untuk mengontrol dan/atau memanipulasikan semua variabel yang relevan.

\section{Hasil dan Pembahasan}

Berdasarkan hasil penelitian yang telah dilakukan, maka data hasil penelitian disajikan dan dianalisis sesuai dengan tujuan penelitian yang diajukan sebelumnya yaitu untuk mengetahui efektivitas layanan penguasaan konten melalui bimbingan kelompok belajar.

\section{Perbedaan Perilaku Menyontek Siswa Saat Ujian Kelompok Eksperimen Sebelum dan Setelah Diberikan Perlakuan Layanan Penguasaan Konten Menggunakan Bimbingan Kelompok Belajar Siswa Saat Ujian}

Data penelitian pada kelompok eksperimen diperoleh dari instrumen penelitian yang telah diberikan kepada 24 orang siswa kelompok eksperimen sebelum perlakan (pretest) dan setelah perlakuan (posttest). Berdasarkan hasil pretest dan posttest perilaku menyontek siswa saat ujian pada kelompok eksperimen diperoleh hasil sebagai berikut: 


\section{Tabel 1}

Hasil Pretest dan Posttest

Perilaku Menyontek Siswa Saat Ujian Kelompok Eksperimen

\begin{tabular}{|c|c|c|c|c|c|}
\hline \multirow{2}{*}{ Interval } & \multirow{2}{*}{ Kategori } & \multicolumn{2}{|c|}{ Pretest } & \multicolumn{2}{|c|}{ Posttest } \\
\hline & & Frekuensi & $\%$ & Frekuensi & $\%$ \\
\hline$>158$ & Sangat tinggi & 6 & 25.00 & 0 & 0 \\
\hline $128-157$ & Tinggi & 16 & 66.67 & 13 & 54.2 \\
\hline $98-127$ & Sedang & 2 & 8.33 & 8 & 33.3 \\
\hline $68-97$ & Rendah & 0 & 0 & 3 & 13 \\
\hline$<67$ & Sangat rendah & 0 & 0 & 0 & 0 \\
\hline \multicolumn{2}{|c|}{ Jumlah } & 24 & 100 & 24 & 100 \\
\hline
\end{tabular}

Berdasarkan tabel 8, dapat diketahui bahwa terdapat perbedaan perilaku menyontek siswa saat ujian pada kelompok eksperimen sebelum dan sesudah mendapatkan perlakuan berupa layanan penguasaan konten dengan menggunakan bimbingan kelompok belajar.

Pada saat pretest, perilaku menyontek 6 orang siswa berada pada kategori sangat tinggi dengan persentase sebesar $25.00 \%, 16$ orang siswa berada pada kategori tinggi dengan persentase $66.67 \%$, 2 orang siswa berada pada kategori sedang dengan persentase $8.33 \%$ dan tidak terdapat siswa yang berada pada kategori rendah dan sangat rendah. Setelah diberikan perlakuan berupa layanan penguasan konten menggunakan bimbingan kelompok belajar terjadi perubahan tingkat perilaku menyontek siswa saat ujian yang dapat dilihat dari hasil posttest, yakni tidak terdapat siswa yang berada pada kategori sangat tinggi, 13 orang siswa berada pada kategori tinggi dengan persentase $54.2 \%, 8$ orang siswa berada pada kategori sedang dengan persentase $33.3 \%$, 3 orang siswa berada pada kategori rendah dengan persentase $13 \%$ dan tidak terdapat siswa yang berada pada kategori sangat rendah.

Berdasarkan pengujian hipotesis pertama, dapat disimpulkan bahwa terdapat perbedaan yang signifikan pada perilaku menyontek siswa saat ujian kelompok eksperimen sebelum dan sesudah diberikan layanan penguasaan konten menggunakan bimbingan kelompok belajar, yakni terjadi pengurangan yang signifikan perilaku menyontek siswa saat ujian kelompok eksperimen setelah diberikan perlakuan. Artinnya bimbingan kelompok belajar bisa digunakan untuk mengurangi perilaku menyontek siswa saat ujian.

Perilaku menyontek yang dimaksud adalah upaya seseorang untuk mendapatkan keerhasilan dengan cara tidak jujur yang melanggar tata tertib ujian, menyangkut : (1) memberikan, mengambil, atau menerima informasi, (2) menggunakan materi atau catatan,dan (3) memanfaatkan prosedur atau proses untuk mendapatkan keuntungan dalam tugas akademik.

Mengurangi perilaku menyontek siswa saat ujian merupakan salah satu tugas dan tanggung jawab guru BK atau konselor sekolah. Adapun bantuan yang diberikan dapat melalui layanan BK, diantaranya melalui layanan penguasaan konten. Pemberian layanan penguasaan konten (PKO) merupakan layanan bantuan kepada individu (sendiri ataupun kelompok) untuk menguasai kemampuan atau kompetensi tertentu melalui kegiatan belajar (Prayitno, 2012:89).

Pada penelitian ini, bimbingan kelompok belajar yang dilaksanakan adalah dengan membagi siswa ke dalam 4 kelompok. Kemudian peneliti menjelaskan tugas yang akan dilaksanakan siswa di dalam kelompok sesuai dengan materi yang telah disiapkan peneliti. Setelah siswa dibagi, kemudian peneliti mengamati bagaimana kegiatan dan partisipasi siswa dalam kelompok belajarnya. Melalui bimbingan kelompok belajar ini menjadikan siswa bisa lebih aktif dan paham dalam proses pembelajaran. Menurut Pratikno (2012:22) bahwa belajar kelompok adalah belajar kelompok adalah suatu proses pemberian bantuan kepada individu atau kelompok yang dilakukan secara berkesinambungan, logis dan sistematis yang dilakukan oleh beberapa orang dengan memiliki kemampuan untuk berbuat dengan kesatuannya agar memperoleh perubahan tingkah laku dan belajar menjadi lebih efektif.

Keberhasilan pemberian layanan penguasaan konten menggunakan bimbingan kelompok belajar diperkuat dengan hasil temuan pada hipotesis pertama yang menyatakan bahwa terdapat perbedaan yang signifikan perilaku menyontek siswa saat ujian kelompok eksperimen sebelum dan sesudah diberikan layanan penguasaan konten menggunakan bimbingan kelompok belajar.

Berdasarkan hal yang telah dijelaskan di atas, maka layanan penguasaan konten menggunakan bimbingan kelompok belajar dapat diberikan dalam rangka mengurangi perilaku menyontek siswa saat ujian. Dengan adanya layanan penguasaan konten menggunakan bimbingan kelompok belajar menjadikan siswa paham akan kerugian perilaku menyontek.

Efektivitas Layanan Penguasaan Konten Melalui Bimbingan Kelompok Belajar dalam Mengurangi Perilaku Menyontek Siswa saat Ujian 
2. Perbedaan Perilaku Menyontek Siswa Saat Ujian Kelompok Kontrol Sebelum dan Setelah Diberikan Perlakuan Layanan Penguasaan Konten Tanpa Menggunakan Bimbingan Kelompok Belajar

Data penelitian pada kelompok kontrol diperoleh dari instrumen penelitian yang telah diberikan kepada 24 orang siswa kelompok kontrol sebelum perlakuan (pretest) dan setelah perlakuan (posttest). Berdasarkan hasil pretest dan posttest perilaku menyontek siswa saat ujian pada kelompok kontrol diperoleh hasil sebagai berikut:

Tabel 2

Hasil Pretest dan Posttest

Perilaku Menyontek Siswa Saat Ujian Kelompok Kontrol

\begin{tabular}{|c|c|c|c|c|c|}
\hline \multirow{3}{*}{ Interval } & \multirow{3}{*}{ Kategori } & \multirow{2}{*}{\multicolumn{2}{|c|}{ Pretest }} & \multirow{2}{*}{\multicolumn{2}{|c|}{ Posttest }} \\
\hline & & & & & \\
\hline & & Frekuensi & $\%$ & Frekuensi & $\%$ \\
\hline$>158$ & Sangat tinggi & 2 & 8.3 & 0 & 0 \\
\hline $128-157$ & Tinggi & 16 & 66.7 & 14 & 58.3 \\
\hline $98-127$ & Sedang & 6 & 25.0 & 10 & 41.7 \\
\hline $68-97$ & Rendah & 0 & 0 & 0 & 0 \\
\hline$<67$ & Sangat rendah & 0 & 0 & 0 & 0 \\
\hline & Jumlah & 24 & 100 & 24 & 100 \\
\hline
\end{tabular}

Berdasarkan tabel 2, dapat diketahui bahwa terdapat perbedaan perilaku menyontek siswa saat ujian pada kelompok kontrol sebelum dan sesudah mendapatkan perlakuan berupa layanan penguasaan konten tanpa bimbingan kelompok belajar. Pada saat pretest, perilaku menyontek 2 orang siswa berada pada kategori sangat tinggi dengan persentase sebesar $8.3 \%, 16$ orang siswa berada pada kategori tinggi dengan persentase $66.7 \%, 6$ orang siswa berada pada kategori sedang dengan persentase $25.0 \%$ dan tidak ada siswa yang berada pada kategori rendah dan sangat rendah. Setelah diberikan perlakuan berupa layanan penguasaan konten tanpa bimbingan kelompok belajar terjadi perubahan tingkat perilaku menyontek siswa saat ujian yang dapat dilihat dari hasil posttest, yakni tidak ada siswa yang berada pada kategori sangat tinggi, 14 orang siswa berada pada kategori tinggi dengan persentase $58.3 \%, 10$ orang siswa berada pada kategori sedang dengan persentase $41.7 \%$ dan tidak terdapat siswa yang berasa pada kategori rendah dan sangat rendah.

Pemberian layanan penguasaan konten untuk mengurangi perilaku menyontek siswa saat ujian pada kelompok kontrol dilakukan tanpa menggunakan bimbingan kelompok belajar. Dari data hasil penelitian, diketahui bahwa tidak terdapat perbedaan yang signifikan pada perilaku menyontek siswa saat ujian kelompok kontrol sebelum dan sesudah diberi perlakuan. Dikatakan tidak signifikan karena hanya terjadi perbedaan mean sebelum dan sesudah diberi perlakuan, sementara tidak terjadinya perbedaan kategori. Perubahan tersebut dikarenakan kelompok kontrol tidak mendapat perlakuan khusus yaitu layanan penguasaan konten menggunakan bimbingan kelompok belajar

Layanan penguasaan konten dalam mengurangi perilaku menyontek siswa saat ujian kelompok kontrol diberikan secara konvensional, yaitu teknik ceramah dan tanya jawab. Senada dengan pernyataan tersebut, metode atau teknik yang digunakan dalam penyajian layanan penguasaan konten menurut Prayitno (2012:97) adalah penyajian, tanya jawab dan diskusi.

Pemberian layanan penguasaan konten secara konvensional atau tanpa menggunakan bimbingan kelompok belajar ini menyajikan materi yang sama diberikan pada kelas eksperimen. Pada hasil penelitian ini tergambarlah bahwa kurang efektifnya pemberian layanan penguasaan konten secara konvensional. Hal ini didukung dengan hasil penelitian yang menunjukan tidak adanya perubahan signifikan sebelum dan setelah diberikan perlakuan layanan penguasaan konten pada kelas kontrol.

3. Perbedaan Perilaku Menyontek Siswa Saat Ujian Kelompok Eksperimen dan Kelompok Kontrol Setelah Diberi Perlakuan

Data penelitian ini adalah hasil posttest kelompok eksperimen dan kelompok kontrol. Data ini disajikan bertujuan untuk mengetahui keefektifan layanan penguasaan konten menggunakan bimbingan kelompok belajar pada kelompok eksperimen dan tanpa bimbingan kelompok pada kelompok kontrol. Adapun perbedaan frekuensi hasil posstest perilaku menyontek siswa saat ujian pada kelompok eksperimen dan kelompok kontrol dapat dilihat pada tabel berikut: 


\begin{tabular}{|c|c|c|c|c|c|}
\hline \multirow{3}{*}{ Interval } & \multicolumn{5}{|c|}{$\begin{array}{c}\text { Tabel } 3 \\
\text { Hasil Posttest Perilaku Menyontek Siswa Saat Ujian } \\
\text { Kelompok Eksperimen dan kelompok Kontrol }\end{array}$} \\
\hline & \multirow{2}{*}{ Kategori } & \multicolumn{2}{|c|}{ Frekuensi } & \multirow[b]{2}{*}{$\mathbf{N}$} & \multirow{2}{*}{$\%$} \\
\hline & & Eksperimen & Kontrol & & \\
\hline$>158$ & Sangat tinggi & 0 & 0 & 0 & 0 \\
\hline $128-157$ & Tinggi & 13 & 14 & 27 & 56.25 \\
\hline $98-127$ & Sedang & 8 & 10 & 18 & 37.5 \\
\hline $68-97$ & Rendah & 3 & 0 & 3 & 6.25 \\
\hline$<67$ & Sangat rendah & 0 & 0 & 0 & 0 \\
\hline \multicolumn{2}{|l|}{ Jumlah } & 24 & 24 & 48 & 100 \\
\hline
\end{tabular}

Berdasarkan tabel 3, dapat dilihat hasil posttest pada masing-masing kelompok. Pada kelompok eksperimen, tingkat perilaku menyontek siswa saat ujian yakni tidak terdapat siswa yang berada pada kategori sangat tinggi, 13 orang siswa berada pada kategori tinggi dengan persentase $54.2 \%, 8$ orang siswa berada pada kategori sedang dengan persentase $33.3 \%, 3$ orang siswa berada pada kategori rendah dengan persentase $13 \%$ dan tidak terdapat siswa yang berada pada kategori sangat rendah.

Selanjutnya, tingkat perilaku menyontek siswa saat ujian pada kelompok kontrol yakni tidak ada siswa yang berada pada kategori sangat tinggi, 14 orang siswa berada pada kategori tinggi dengan persentase $58.3 \%$, 10 orang siswa berada pada kategori sedang dengan persentase $41.7 \%$ dan tidak terdapat siswa yang berasa pada kategori rendah dan sangat rendah. Berdasarkan hasil uji statisitik menunjukan adanya perbedaan perilaku menyontek siswa saat ujian pada kelompok eksperimen dan kelompok kontrol. Perbedaan perilaku menyontek siswa saat ujian terjadi karena adanya perbedaan perlakuan yang diterima oleh masing-masing kelompok. Meskipun materi dan banyaknya perlakuan yang diberikan sama-sama berjumlah 4 kali. Kelompok kontrol diberikan perlakuan berbeda dari kelompok ekperimen yaitu pemberian layanan penguasaan konten secara konvensional atau tanpa bimbingan kelompok belajar. Peneliti memberikan materi dan konten-konten mengenai perilaku menyontek siswa saat ujian dengan teknik ceramah dan tanya jawab. Kemudian peneliti mempersilahkan siswa untuk bertanya apabila terdapat hal yang belum dipahami. Selama proses pembelajaran berlangsung, tidak banyak siswa yang merespon pertanyaan dari peneliti. Siswa yang aktif biasanya selalu sama pada setiap pertemuan, dan sulit untuk mendorong siswa yang lain untuk ikut aktif.

Selanjutnya, untuk kelompok eksperimen diberikan perlakuan layanan penguasaan konten menggunakan bimbingan kelompok belajar. Dalam pelaksanaan pembelajaran, guru hendaknya dapat membantu siswa untuk lebih mudah memahami pelajaran dan melibatkan siswa untuk lebih aktif serta menjadikan proses pembelajaran sebagai hal yang menyenangkan. Begitupun untuk guru Bimbingan dan Konseling, yang juga dapat lebih inovatif untuk menggunakan media, model ataupun strategi pembelajaran dalam pemberian layanan. Layanan penguasaan konten yang diberikan guru BK bertujuan agar siswa menguasai aspek-aspek konten (kemampuan atau kompetensi) tertentu yang berguna untuk menambah wawasan dan pemahaman, mengarahkan penilaian dan sikap, menguasai cara-cara tertentu dalam rangka memenuhi kebutuhan dan mengatasi masalah-masalahnya (Tohirin, 2011:159).

Pemilihan model pembelajaran perlu didasari oleh kesesuaian tujuan dari pembelajaran itu sendiri. Model pembelajaran bimbingan kelompok belajar merupakan salah satu model dalam pembelajaran yang mengajak siswa untuk belajar secara kelompok turut pula merealisasikan tujuan pendidikan dan pengajaran dan untuk belajar mengatasi kesullitan secara bersama-sama, terutama dalam hal pelajaran.

\section{Kesimpulan}

Berdasarkan hasil penelitian yang diperoleh, dan setelah melakukan analisis statistik, serta pengujian hipotesis, maka secara umum dapat disimpulkan bahwa layanan penguasaan konten menggunakan bimbingan kelompok belajar dapat mengurangi perilaku menyontek siswa saat ujian. Secara khusus temuan dalam penelitian ini adalah sebagai berikut : 
1. Terdapat perbedaan yang signifikan pada perilaku menyontek siswa saat ujian kelompok eksperimen sebelum dan sesudah diberikan layanan penguasaan konten menggunakan bimbingan kelompok belajar.

2. Tidak terdapat perbedaan yang signifikan pada perilaku menyontek siswa saat ujian kelompok kontrol sebelum dan sesudah diberikan perlakuan layanan penguasaan konten tanpa menggunakan bimgingan kelompok belajar.

3. Terdapat perbedaan yang signifikan perilaku menyontek siswa saat ujian antara kelompok eksperimen yang mengikuti layanan penguasaan konten menggunakan bimbingan kelompok belajar dan perilaku menyontek siswa saat ujian kelompok kontrol yang mengikuti layanan penguasaan konten tanpa menggunakan bimbingan kelompok belajar.

Hasil pengujian ketiga hipotesis dalam penelitian ini menunjukan bahwa layanan penguasaan konten menggunakan bimbingan kelompok belajar lebih efektif dalam mengurangi perilaku menyontek siswa saat ujian. Layanan penguasaan konten secara konvensional dapat mengurangi perilaku menyontek siswa saat ujian, namun peningkatan rata-rata skor tidak sebanyak pada layanan penguasaan konten dengan bimbingan kelompok belajar.

\section{Kepustakaan}

A.Muri Yusuf. 2005. Metodologi Penelitian. Padang: UNP Press.

Bimo Walgito. 2010. Bimbingan + Konseling. Yogyakarta: Andi Offset.

Dody Hartanto. 2012. Bimbingan \& Konseling : Menyontek Mengungkap akar masalah dan Solusinya. Jakarta : Indeks.

Erlina Wilda. 2013. Faktor Penyebab Peserta Didik Melakukan Perilaku Menyontek Dalam Ujian. Jurnal.

Hurlock, E.B. 1980. Psikologi Perkembangan: Suatu Pendekatan Sepanjang Rentang Kehidupan. Bandung : Nusa Media.

Intan Sari, dkk. 2013. Locus of Control dan Perilaku Menyontek serta Implikasinya Terhadap Bimbingan dan Konseling. Jurnal. Volume.

Kiki Nurmayasari \& Hadjam Murusdi.2015. Hubungan Antara Berpikir Positif Dan Perilaku Menyontek Pada Siswa Kelas X SMK Koperasi Yogyakarta. Yogyakarta. Jurnal. Vol. 3, No 1.

Maysari. 2015. Hubungan Self Efficacy Akademik dengan Perilaku Menyontek Siswa. Skripsi tidak diterbitkan. Padang : Universitas Negeri Padang.

Muhibbin Syah. 2008. Psikologi Belajar. Jakarta:Rajafrafindo Persada.

Nana Sudjana. 2009. Dasar-dasar Proses Belajar Mengajar. Bandung : Sinar Baru Algensindo.

Ormrod,J.E.2009. Psikologi Pendidikan. Jilid 1. Jakarta : Erlangga.

Pratikno. (2012). Pengaruh Perhatian Orang Tua dan Intensitas Belajar Kelompokterhadap Minat Belajar Siswa Kelas V Sekolah Dasar Negeri Se-Gugus Cahyana Kecamatan Rembang Purbalingga tahun Pelajaran 2011/ 2012. Skripsi. Yogyakarta: FIP UNY.

Prayitno \& Erman Amti. 2004. Dasar-Dasar Bimbingan dan Konseling. Jakarta : Rineka Cipta.

Prayitno. 2012. Jenis Layanan dan Kegitan Pendukung Konseling. Padang : FIP UNP.

Punaji Setyosari. 2013. Metode Penelitian : Pendidikan \& Pengembangan. Jakarta : Prenada Media Group.

Rahmawati, dkk. 2015. Perilaku menyontek ditinjau dari orientasi tujuan belajar siswa SMA/MA di Surakarta. Jurnal. ISBN: 978-602-8580-19-9. 
Rohana. Hubungan Self Efficacy dan Konfomitas Teman Sebaya terhadap Perilaku Menyontek Siswa SMP Bhakti Loa Janan. Jurnal.3 (3).

Rusydan Ubaidi Hamdani. Menyontek...?Yuk!!Hmm...,Nggak Ah!!. 2014. Jakarta: Transmedia.

Silvano,dkk.2008. Budaya Menyontek. Diambil tanggal 18 Februari 2017 dari www.slideshare.net.

Sujana \& Wulan. 1994. Hubungan Antara Pusat Kendali Internal dengan Intensi Menyontek. Jurnal Psikologi. No 2/XXI.

Sumadi Suryabrata. 2012. Metodologi Penelitian. Jakarta : Rajawali Pers.

Tohirin. 2009. Bimbingan dan Konseling di Sekolah dan Madrasah. Jakarta : Raja Grafindo Persada.

Trianto. 2011. Pengantar Penelitian Pendidikan Bagi Pengembangan Profesi Pendidikan \& Tenaga Kependidikan. Jakarta : Prenada Media Group.

Tsany Lutfiyanti dan Mochamad Nursalim. 2013. Penerapan bimbingan kelompok belajar untuk meningkatkan kemampuan interaksi sosial siswa kelas XI IPA C SMAN 2 Tuban. Jurnal. Volume 04 nomor 012013.338-347.

Undang-undang No. 20 Tahun 2003 tentang Sistem Pendidikan Nasional.

Virza agustin. 2013. Perilaku Menyontek Siswa SMA Negeri di Kota Padang Serta Upaya Pencegahan Oleh Guru BK. Skripsi. 